\title{
SOAL ESSAY MATERI ARITMATIKA SOSIAL UNTUK KEMAMPUAN BERPIKIR KRITIS MATEMATIS SISWA KELAS VII
}

\author{
Rika Handayani ${ }^{1}$, Kashardi' ${ }^{2}$, Yuriska Destania ${ }^{3}$ \\ Universitas Muhammadiyah Bengkulu ${ }^{1,2,3}$ \\ rikahandayani158@gmail.com¹, kashardi@umb.ac.id ${ }^{2}$,yuriskadestania@yahoo.com ${ }^{3}$
}

\begin{abstract}
ABSTRAK
Penelitian ini bertujuan untuk menghasilkan produk berupa soal-soal kemampuan berpikir kritis matematis siswa yang valid dan praktis. Penelitian ini merupakan penelitian pengembangan menggunakan model pengembangan Akker. Penelitian ini dilakukan di SMP Negeri 17 Kota Bengkulu dan dilaksanakan pada bulan Juli tahun ajaran 2019/2020. Subjek yang digunakan dalam penelitian ini yaitu siswa SMP Negeri 17 kelas VII A. Data dalam penelitian ini dianalisis secara deskriptif kualitatif. Kevalidan soal diketahui dari hasil penilaian validator pada lembar validasi yang menyatakan soal-soal dikembangkan dengan baik berdasarkan materi, konstruk, dan bahasa. Kepraktisan diketahui dari hasil one-to-one. Hasil penelitian pengembangan ini menghasilkan 14 butir soal yang telah melalui tahap expert review dan one-toone.
\end{abstract}

Kata kunci : soal, berpikir kritis

\begin{abstract}
The purpose of this study is to create products in the form of valid and practical questions about students' mathematical critical thinking skills. This study is a development study that employs the Akker development model. This study was carried out at SMP Negeri 17 Bengkulu City in July of the 2019/2020 school year. Students from SMP Negeri 17 class VII A were used in this study. This study's data was analyzed both descriptively and qualitatively. The validity of the questions is determined by the validator's assessment on the validation sheet, which states that the questions are well developed in terms of material, construct, and language. One-to-one results demonstrate practicality. The findings of this development research resulted in 14 items that were declared valid and practicable after expert review and one-on-one sessions.
\end{abstract}

Keywords : questions, critical thinking

\section{PENDAHULUAN}

Matematika adalah suatu alat untuk mengembangkan cara berpikir (Hudojo, 2005). Sehingga matematika merupakan mata pelajaran yang sangat penting karena matematika adalah salah satu mata pelajaran yang merupakan penunjang ilmu pengetahuan dan teknologi. 
Mata pelajaran matematika perlu diberikan kepada semua siswa mulai dari sekolah dasar untuk membekali siswa dengan kemampuan berpikir logis, analitis, sistematis, kritis, dan kreatif, serta kemampuan bekerjasama sehingga siswa mampu memperoleh, mengelola, dan memanfaatkan informasi untuk bertahan hidup pada keadaan yang selalu berubah, tidak pasti, dan kompetitif (Permendiknas No. 22 Tahun 2006). Apalagi berpikir kritis dalam matematika memiliki alur tertentu yang khas matematik (Syahbana, 2012) yaitu melalui penalaran dan pembuktian (Turmudi, 2008).

Menurut Wijaya (2010:72) berpikir kritis yaitu kegiatan menganalisis ide atau gagasan ke arah yang lebih spesifik, membedakannya secara tajam, memilih, mengidentifikasi, mengkaji, dan mengembangkannya ke arah yang lebih sempurna. Dalam proses pembelajaran matematika, berpikir kritis sangat diperlukan agar siswa menjadi semakin mudah dalam memecahkan masalah matematika dan harus dapat dikembangkan dalam pembelajaran.

Berdasarkan observasi yang dilakukan bersamaan dengan magang 3 selama kurang lebih 1 bulan di SMPN 17 Kota Bengkulu masih kurangnya kemampuan berpikir kritis matematis siswa dalam mengerjakan soal-soal. Di mana masih kurangnya soal-soal untuk kemampuan berpikir kritis matematis siswa dalam pembelajaran. Soal-soal yang mengukur kemampuan berpikir kritis matematis masih sedikit serta soal kemampuan berpikir masih tergolong soal umum atau belum terlalu mendalam pada kemampuan berpikir kritis dan belum terlalu diterapkan kepada siswa. Agar permasalahan di atas dapat teratasi yaitu dengan melakukan pengembangan soal untuk kemampuan berpikir kritis matematis.

Soal essay merupakan salah satu cara untuk melihat kemampuan siswa. Soal essay adalah soal yang mengandung permasalahan dan menuntut jawaban siswa berupa uraian-uraian kata yang menggambarkan kemampuan berpikir siswa (Sukardi, 2009). Soal essay dapat dikatakan sebagai soal dengan menggunakan pertanyaan terbuka, dimana siswa diharuskan menjawab sesuai pengetahuan yang dimilikinya. Sehingga untuk dapat mengukur kemampuan berpikir kritis siswa digunakan soal essay.

Soal essay memiliki beberapa kelebihan (Dirman dan Juarsih, 2014: 57) sebagai berikut: a) Peseta didik dapat mengorganisasikan jawaban sendiri, b) Peserta didik tidak dapat menerka jawaban soal, c) Sangat cocok untuk mengukur dan mengevaluasi hasil suatu proses belajar yang kompleks yang sukar diukur dengan mempergunakan soal obyektif, d) Derajat ketepatan dan kebenaran peserta didik dapat dilihat dari kalimat-kalimatnya, e) Dapat melatih peserta didik untuk memilih fakta yang relevan dengan persoalan, dan mengorganisasikannya sehingga dapat mengungkapkan suatu hasil pemikiran yang terintegrasi secara utuh.

Selain mempunyai beberapa kelebihan yang telah diuraikan di atas, soal essay juga memiliki beberapa kelemahan (Dirman dan Juarsih, 2014: 57) diantaranya sebagai berikut: a) Sukar dinilai secara tepat, b) Bahan yang diukur terlalu sedikit sehingga agak sulit untuk mengukur penguasaan peserta didik terhadap keseluruhan kurikulum, c) Sulit mendapatkan soal yang memiliki standar nasional maupun internasional, d) Membutuhkan waktu untuk memeriksanya.

Soal yang baik haruslah memiliki kriteria valid dan praktis. Valid maksudnya soal tepat mengukur apa yang hendak diukur yaitu tepat mengukur kemampuan berpikir kritis matematis siswa. Sedangkan praktis yaitu soal dapat dipahami, terbaca dan dapat digunakan oleh siswa. 
Berdasarkan latar belakang masalah tersebut maka dilakukan penelitian pengembangan soal essay untuk kemampuan berpikir kritis matematis siswa kelas VII pada materi aritmatika sosial. Pada penelitian ini, sesuai dengan kebutuhan maka digunakan validitas isi dan validitas konstruk. Validitas isi disesuaikan dengan kompetensi inti dan kompetensi dasar serta indikator. Validitas konstruk disesuaikan dengan cara memperinci dan memasangkan setiap butir soal untuk kemampuan berpikir kritis matematis. Selain itu perlu juga diperhatikan penggunaan bahasa pada soal yang dikembangkan.

\section{METODE}

Jenis penelitian ini adalah penelitian pengembangan (development research). Penelitian pengembangan adalah penelitian yang ditujukan untuk menghasilkan produk tertentu, dan menguji keefektifan produk tersebut (Sugiyono, 2016). Produk yang dihasilkan dalam pengembangan ini adalah soal-soal kemampuan berpikir kritis yang valid dan praktis.

Penelitian ini dilakukan di SMP Negeri 17 Kota Bengkulu dan dilaksanakan pada bulan Juli tahun ajaran 2019/2020. Subjek yang digunakan dalam penelitian ini yaitu: siswa SMP Negeri 17 kelas VII A.

Metode yang digunakan dalam penelitian ini adalah penelitian pengembangan (development research) dengan model pengembangan Akker (1999). Tahapan pengembangan menurut Akker terdiri dari tahap pendahuluan (preliminary study) dan tahap evaluasi formatif (formative evaluation). Tahap pendahuluan terdiri dari analisis dan desain, sedangkan pada tahap formative evaluation alur desainnya mengacu pada Tessmer (1993).

a. Tahap Pendahuluan (Preliminary Study)

1) Tahap Analisis

Pada tahap ini ditentukan tempat dan subjek penelitian, mengobservasi, melakukan analisis kurikulum, siswa, dan materi. Analisis kurikulum bertujuan untuk mengetahui kurikulum yang digunakan di sekolah, kemudian mengkaji aspek-aspek yang dipelajari siswa. Analisis materi bertujuan untuk mengetahui materi apa yang akan dikembangkan untuk pengembangan soal. Analisis siswa bertujuan untuk mengetahui latar belakang karakteristik siswa. Karateristik siswa yang akan dianalisis adalah pengetahuan siswa dan perkembangan kognitif siswa dalam kemampuan berpikir kritis matematis.

2) Tahap Desain

Desain produk meliputi kisi-kisi soal, dan soal-soal untuk kemampuan berpikir kritis matematis. Hasil desain ini disebut prototype. Masing-masing prototype fokus pada validitas konten yang meliputi materi, konstruksi, dan bahasa.

b. Evaluasi Formatif (Formatif Evaluation)

Tahapan pada evaluasi formatif menurut Tessmer (1993) yaitu: self evaluation, expert review, one-to-one, small group, dan field test.

1) Self Evaluation

Pada tahap ini soal yang telah dibuat dievaluasi kembali baik dari segi isi maupun bahasa yang digunakan.

2) Experts Review

Desain soal yang dibuat disebut prototype pertama berdasarkan self evaluation divalidasi kepada pakar. Pakar terdiri dari 2 dosen pendidikan matematika 
Universitas Muhammadiyah Bengkulu. Produk yang didesain divalidasi berdasarkan materi, konstruk, dan bahasa. Tanggapan dan saran dari validator ditulis pada lembar validasi sebagai bahan untuk merevisi. Produk yang telah direvisi dan valid menurut validator disebut prototype II.

3) One-to-one

Pada tahap ini meminta siswa untuk memberikan tanggapan terhadap soal yang telah diberikan. Uji one-to-one digunakan untuk uji keterbacaan soal. Hasil komentar dari siswa digunakan untuk pertimbangan keterbacaan soal yang telah dibuat. Siswa yang diminta untuk memberikan tanggapan adalah siswa kelas VII SMP, 4 orang siswa kelas VII SMP Negeri 17 Kota Bengkulu, dan 2 orang siswa kelas VII SMP 11 Kota Bengkulu.

4) Small Group

Tahap small group tidak dilakukan, dikarenakan keterbatasan dan situasi pandemi saat ini.

5) Uji lapangan (Field Test)

Tahap uji lapangan (field test) tidak dilakukan, dikarenakan keterbatasan dan situasi pandemi saat ini.

Indikator kemampuan berpikir kritis yang diacu adalah menurut Ennis (Maftukhin, 2013:24) yaitu: 1) Klarifikasi dasar terbagi menjadi 3 indikator yaitu: a. Mengidentifikasi atau merumuskan pertanyaan, b. Menganalisis argumen, dan c. Bertanya dan menjawab pertanyaan. 2) Memberikan alasan suatu keputusan yang terbagi menjadi 2 yaitu: a. Mempertimbangkan kredibilitas suatu sumber, dan b. Mengobservasi dan mempertimbangkan hasil obsevasi. 3) Menyimpulkan yang terdiri dari 3 yaitu: a. Membuat deduksi dan mempertimbangkan hasil deduksi, b. Membuat induksi dan mempertimbangkan hasil induksi, dan c. Membuat dan mempertimbangkan nilai keputusan. 4) Klarifikasi lebih lanjut yang terdiri 2 yaitu: a. Mengidentifikasi istilah dan b. mempertimbangkan definisi. 5) Dugaan dan keterpaduan yang terdiri 2 yaitu: a. Mempertimbangkan dan memikirkan secara logis, dan b. Mengabungkan.

Dalam penelitian ini, instrumen pengumpulan data yang digunakan yaitu: 1) dokumen yang berupa data tentang pengetahuan siswa dan kurikulum yang sedang berlaku di sekolah. Dokumen ini dikumpulkan untuk dijadikan sebagai acuan dalam mendesain soal-soal kemampuan berpikir kritis matematis siswa; 2) lembar validasi yang digunakan untuk mengukur kevalidan soal yang akan ditujukan kepada validator yaitu dosen dan guru matematika SMP. Hasil dari analisis dijadikan pada tahap expert review untuk mendapatkan data validasi berdasarkan materi, konstruk dan bahasa; 3) lembar wawancara yang dilakukan pada tahap one-to-one untuk memberikan tanggapan tentang soal kemampuan berpikir kritis matematis siswa.

Data yang digunakan dalam penelitian ini dianalisis secara kualitatif, yaitu: dokumen yang diperoleh saat preliminary dan self evaluation berupa data siswa kelas VII SMP dan data pengetahuan siswa tentang aritmatika sosial, data hasil validasi expert review dan uji one-to-one. Teknik analisis data secara kuantitatif yaitu pada tahap small group, hasil jawaban siswa dilakukan analisis secara kuantitatif untuk memperoleh tingkat kesukaran butir soal dan daya pembeda butir soal. Tetapi, pada penelitian ini teknik analisis data kuantitatif tidak dilakukan.

Dalam penelitian ini spesifikasi produk yang baik dalam pengembangan soal untuk kemampuan berpikir kritis matematis adalah: 
1. Soal harus valid secara kualitatif berdasarkan materi, konstruk, dan bahasa.

2. Soal praktis pada tahap one-to-one.

3. Soal dikatakan baik secara kuantitatif dengan syarat:

a. Tingkat kesukaran ( $p i)$ soal berada pada kategori sedang, yaitu: $0,30 \leq p \leq 0,70$

b. Indeks daya beda soal $(d i)>0,2$

Berdasarkan uraian di atas, maka pada penelitian ini spesifikasi produk yang digunakan adalah soal valid dan praktis secara kualitatif.

\section{HASIL DAN PEMBAHASAN}

Langkah-langkah pengembangan soal mengikuti tahap-tahap yaitu Preliminary, self evaluation, expert reviews dan one-to-one. Tahap-tahapan yang dilalui dalam penelitian pengembangan soal ini sebagai berikut :

\section{Hasil pada tahap Preliminary}

a. Analisis

Pada tahap ini, dilakukan beberapa analisis yaitu sebagai berikut:

1) Analisis kurikulum

Pada tahap ini dilakukan identifikasi kemampuan yang harus dicapai dalam pembelajaran matematika di SMPN 17 Kota Bengkulu. Kurikulum yang digunakan adalah kurikulum 2013. Pada kurikulum ini diharapkan bisa memunculkan kemampuan berpikir kritis.

2) Analisis materi

Pada analisis materi ini dipilih kompetensi inti dan kompetensi dasar pada pokok bahasan aritmatika sosial yaitu salah satu materi yang ada pada Kurikulum 2013 untuk sekolah menengah pertama. Selain itu, pokok bahasan ini bisa diaplikasikan dalam kehidupan sehari-hari. Penggunaan pokok bahasan juga telah disesuaikan dengan waktu penelitian dan waktu diberikannya materi oleh guru. Sehingga ketika penelitian dilaksanakan siswa telah terlebih dahulu mempelajari materi tersebut.

3) Analisis siswa

Pada analisis ini diketahui latar belakang pengetahuan bahwa siswa sudah mempelajari materi aritmatika sosial di sekolah dengan guru. Sehingga banyak konsep-konsep yang telah diketahui siswa, rata-rata siswa kelas VII SMP berumur 12-13 tahun. Siswa tersebut memiliki kemampuan heterogen, yang dilihat berdasarkan proses pembelajaran matematika di kelas, sehingga siswa dikelompokkan menjadi siswa berkemampuan tinggi, sedang, dan rendah.

b. Desain

Hasil dari analisis kurikulum, analisis materi, analisis siswa dijadikan acuan untuk mendesaian soal kemampuan berpikir kritis matematis. Langkah awal yang dilakukan pada tahap pendesainan adalah penyusunan kisi-kisi soal dengan analisis silabus dan materi yang dipelajari di kelas VII semester 2 . Materi yang diteliti yaitu aritmatika sosial. Kompetensi dasar (KD) yang harus dicapai menggunakan konsep aritmatika sosial. Soal yang didesain disesuaikan dengan indikator kemampuan berpikir kritis matematis. Hasil dari desain produk ini disebut prototype. 


\section{Hasil pada tahap Formative Evaluation}

Pada tahap self evaluation, prototype yang telah didesain berdasarkan materi dan indikator yang berjumlah 20 soal, soal dinilai dan diperbaiki sendiri secara materi, konstruksi, dan bahasa. Hal ini dilakukan sebelum proses expert review yang akan divalidasi oleh pakar. Hasil dari tahap ini disebut prototype 1.

Pada tahap expert review, hasil soal yang telah didesain untuk kemampuan berpikir kritis matematis divalidasi oleh dua validator, yaitu dua dosen Pendidikan Matematika Universitas Muhammadiyah Bengkulu, Dr. Kashardi, M.Pd. dan Mardiah Syofiana, M.Pd. Soal yang didesain divalidasi berdasarkan materi, konstruksi, dan bahasa. Validasi soal ini merupakan analisis kualitatif terhadap butir soal. Hasil validasi para validator tertulis pada lembar komentar dan saran yang digunakan untuk merevisi prototype 1 .

Prototype 1 divalidasi oleh 2 orang validator. Secara keseluruhan dari 20 soal yang dibuat, diperoleh hasil: perlu perbaikan soal agar sesuai dengan indikator kemampuan berpikir kritis, setiap penggunaan nama orang awalan harus kapital dan perbaikan pada penulisan yang sesuai dengan EYD, penggunaan kalimat tanya, penulisan diperbaiki, soal yang kurang jelas, angka yang terlalu besar, pertanyaan serta jawaban dari alternatif lain belum ada, soal masih belum sesuai dengan konteks dunia nyata. Untuk soal nomor 3, 6, 10, 19 dihapuskan. Angka yang digunakan cukup besar untuk anak SMP dan soal tidak terlalu menarik karena soal yang seperti ini cukup sering dipakai, soal masih belum sesuai dengan indikator kemampuan berpikir kritis dan soal kurang jelas membuat bingung, serta tidak sesuai dengan dunia nyata. Berdasarkan komentar dan saran yang diberikan oleh kedua validator yaitu soal dihapuskan.

Setelah soal dilakukan revisi pada validasi 1 maka dilanjutkan validasi 2 . Dimana prototype 1 yang sudah direvisi dan dilakukan validasi berikutnya. Adapun komentar atau saran dan keputusan revisi sebagai berikut: Soal 1,2,3,4, 5, 10, 12 dinyatakan valid oleh kedua validator. Untuk soal nomor 6, 7, dan 8, hanya validator 2 menyatakan kalimat tanya yang masih belum jelas untuk menuntun jawaban terurai, sehingga diperbaiki. Untuk soal nomor 9, validator 2 meminta penggunaan kalimat "akan memilih" lebih baik diganti menjadi "apa yang sebaiknya". Untuk soal nomor 11, menurut validator 2 jawaban dari indikator yang menentukan alternatif-alternatif cara lain dalam menyelesaikan masalah belum ada, sehingga diperbaiki. Untuk soal nomor 13, menurut validator 2 soal masih belum jelas, sehingga soal dilakukan perbaikan atau digantikan dengan yang baru. Untuk soal nomor 14, menurut validator 2 pengejaan masih salah dan penambahan kalimat tanya "berikan alasanmu", sehingga diperbaiki. Untuk soal nomor 15, validator 2 meminta ditambahkan kalimat "akan menjual hasil panenannya" dan kalimat tanya diganti menjadi "berapa kg yang dapat dijual Pak Damar?" sehingga diperbaiki.

Prototype 1 valisasi 3 divalidasi oleh 2 orang validator. Adapun komentar atau saran dan keputusan revisi sebagai berikut: Soal nomor 1, 2, 3, 4, 5, 6, 8, 9, $10,11,12,14,15$ valid. Untuk soal nomor 7 , menurut validator 2 jawaban pada soal bagian indikator menentukan alternatif cara lain dalam menyelesaikan masalah tidak sesuai, sehingga soal diperbaiki dimana penghapusan di bagian indikator menentukan alternatif cara lain dalam menyelesaikan masalah. Untuk soal nomor 13, menurut validator 2 soal masih belum jelas, sehingga soal dihapuskan. 
Prototype 1 divalidasi ke 4 oleh 2 orang validator. Adapun komentar atau saran dan keputusan revisi sebagai berikut: Pada validasi ke 4 semua soal sebanyak 14 buah dinyatakan valid. Soal yang sudah valid ini dinamakan prototype II yang akan dilakukan ujicoba pada tahapan one-to-one untuk mengetahui keterbacaan soal.

Selanjutnya masuk pada tahapan One-to-one. Setelah soal selesai divalidasi oleh para pakar dengan menghasilkan 14 soal yang valid. Selanjutnya soal diujicobakan dengan 6 orang siswa SMP kelas VII dengan cara berhadapan satu lawan satu. Pada ujicoba satu lawan satu siswa diminta membaca, memahami maksud dan tujuan, dan memberikan komentar terhadap soal yang diberikan. Dari komentar dan saran dari 6 siswa tersebut secara umum siswa dapat memahami soal-soal kemampuan berpikir kritis matematis dan soal dapat digunakan, walaupun ada beberapa soal yang sulit untuk mereka, tetapi siswa memahami maksud dan tujuan soal yang diberikan. Soal-soal tersebut dapat dikatakan sudah praktis yaitu dimana terbaca dan dimengerti oleh siswa.

Tabel 1. Prototype II hasil experts review dan one-to-one

1. Akibat wabah covid-19 banyak menyerang seluruh wilayah di Provinsi Indonesia yang menyebabkan sekolah, perkuliahan, kantor dan tempat wisata diliburkan, Presiden membuat kebijakan tetap di rumah dan tidak berpergian ke tempat ramai. Hal ini membuat Ratna ingin melakukan donasi dengan berjualan bunga secara online. Ratna mengeluarkan dana sebesar Rp.500.000,00 untuk menjalankan usaha tersebut. Jika pada hari minggu Ratna mulai berjualan dengan mendapatkan keuntungan sebesar $25 \%$, berapa besarnya pendapatan yang diperoleh Ratna pada hari tersebut?

2. Pak Damar merupakan seorang pedagang tomat. Pak Damar membeli tomat pada petani sebanyak $50 \mathrm{~kg}$ dengan harga Rp6.500,00 per $\mathrm{kg}$, kemudian $30 \mathrm{~kg}$ diantaranya dijual kembali dengan harga Rp8.000,00 per $\mathrm{kg}$ dan sisanya dijual dengan harga Rp7.000,00 per kg. Hitunglah:

a. Berapa harga keseluruhan pembelian tomat

b. Berapa harga keseluruhan penjualan tomat

c. Berapa keuntungan atau rugi

3. Saat ini penyebaran virus covid-19 sangat tinggi sehingga pemerintah menghimbau seluruh masyarakat menggunakan masker minimal masker kain. Karena himbauan tersebut Ani dan Rina akan membeli masker, pedagang menetapkan harga masker satu lusin Rp.78.000,00. Ani ingin membeli satu masker sedangkan Rina 5 masker.

a. Berapa harga yang harus Ani bayar?

b. Berapa harga yang harus Rina bayar?

4. Pada saat sebelum covid-19 Dewi membeli sebuah kalung seharga Rp.800.000,00 pada masa pandemi seperti ini Dewi mengalami masalah keuangan yang membuatnya memutuskan untuk menjual kalungnya dengan harapan keuntungan dari penjualan kalung tersebut sebesar 50\%. Berapa harga jual yang seharusnya? 
5. Himbauan di rumah saja yang diakibatkan oleh pandemic covid-19, membuat Pak Ahmat tidak dapat berjualan sehinga Pak Ahmat memutuskan untuk meminjam uang di bank sebesar Rp.150.000,00 dalam satu tahun besar angsuran yang harus dibayar Rp.186.000,00. Tentukan

a. Besar bunga yang ditanggung oleh Pak Ahmat selama setahun

b. Besar bunga yang ditanggung oleh Pak Ahmat setiap bulan

c. Besar persentase bunga pertahun yang ditanggung Pak Ahmat

d. Besar persentase bunga perbulan yang ditanggung Pak Ahmat

6. Ade mampu menjual satu set baju olahraga seriap hari rata-rata 15 set baju olahraga. Satu set dihargai Rp.250.000,00. Berapa besar pajak UMKM sebesar 2\% yang mesti dibayarkan Ade 1 bulan (30 hari)?

7. Sebuah toko emas "bunga" memberikan tiga jenis penawaran dalam penjualan gelang $X$. Ketiga jenis sistem pembayaran tersebut disajikan dalam tabel berikut.

\begin{tabular}{|l|l|l|l|}
\hline $\begin{array}{l}\text { Jenis } \\
\text { angsuran }\end{array}$ & $\begin{array}{l}\text { Uang } \\
\text { muka } \\
\text { (rupiah) }\end{array}$ & $\begin{array}{l}\text { Angsuran } \\
\text { perbulan } \\
\text { (rupiah) }\end{array}$ & $\begin{array}{l}\text { Lama } \\
\text { angsuran }\end{array}$ \\
\hline A & 1.000 .000 & 450.000 & 35 bulan \\
\hline B & 1.700 .000 & 430.000 & 35 bulan \\
\hline C & 2.300 .000 & 420.000 & 35 bulan \\
\hline
\end{tabular}

Di antara ketiga pilihan tersebut, manakah sistem pembayaran yang memberikan bunga terkecil? Jelaskan!

8. Rahma memiliki toko jam tangan original. Dia menjual jam tangan baru senilai Rp.500.000,00 harga belum termasuk PPN. Nina membeli jam tersebut dengan PPN $10 \%$. Berapa besar uang yang mesti dibayar oleh Nina agar dapat membeli jam tangan tersebut?

9. Situasi pandemic covid-19 mengeluarkan kebijakan new normal. Situasi ini membuat toko cahaya membuka lagi tokonya. Bima membeli celana di toko tersebut seharga Rp.150.000,00 kemudian mendapat voucher senilai Rp.50.000,00 voucher hanya dapat digunakan sekali untuk membeli barang minimal harga Rp.150.000,00. Bima menemukan sepatu seharga Rp.300.000,00 yang bertuliskan diskon 20\%, sesuai aturan toko Bima hanya dapat memilih salah satu yaitu voucher atau diskon saja tidak bisa keduanya. Maka apa yang sebaiknya Bima pilih menggunakan voucher atau diskon? Jelaskan!

10. Manda membuka tabungan di bank sebesar Rp.200.000,00 dengan suku bunga tunggal 6\% pertahun. Pada saat Manda akan mengambil uang, jumlah uang Amanda menjadi Rp.280.000,00. Berapa lama Amanda menabung?

11. Jika kalian sebagai direktur bank pemberi pinjaman modal kepada pengusaha kecil menengah. Manakah yang akan kalian pilih:

a. Kalian akan memberikan bunga $15 \%$ pertahun 
b. Kalian memberikan bunga $2 \%$ pertahun

c. Kalian akan memberikan bunga 120.000 untuk pinjaman sebesar Rp 1.000 .000

Sistem pembayaran manakah yang memberikan bunga terkecil? Jelaskan!

12. Perhatikan gambar!

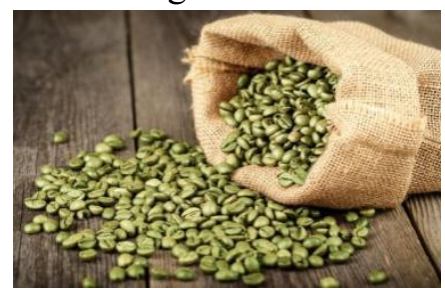

Diandra membeli kopi dengan jenis yang berbeda. Karung pertama tertulis berat bersih $30 \mathrm{~kg}$ dibeli dengan harga Rp.350.000,00. Karung kedua tertuliskan berat bersih $30 \mathrm{~kg}$. Diandra mencampur kedua kopi tersebut, kemudian mengemasnya dalam ukuran berat bersih $3 \mathrm{~kg}$. Besar campuran tersebut dijual dengan harga Rp.33.000,00 perkemasan. Jika keuntungan perkemasan 20\%, tentukan harga beli kopi kedua? Adakah cara lain dalam menyelesaikannya? Jika ada jelaskan!

13. Melani akan membeli minuman dimana pada kemasan pertama tertulis berat bersih $330 \mathrm{ml}$ dijual dengan harga Rp.6.000,00, kemasan kedua tertulis berat bersih $450 \mathrm{ml}$ dengan harga Rp.9.000,00, dan kemasan ketiga tertulis berat bersih $600 \mathrm{ml}$ dengan harga Rp.15.000,00. Minuman mana yang akan Melani pilih? Berikan alasanmu!

14. Perhatikan gambar!

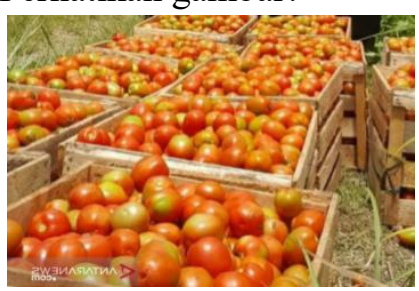

Pak Darman baru saja memanen tomat sebanyak 5 peti dan akan menjual hasil panen. Setiap peti memiliki berat kotor $25 \mathrm{~kg}$ dan berat tempat tomat $4 \%$. Berapa $\mathrm{kg}$ tomat yang dapat dijual Pak Damar?

Pada proses tahapan small group rencananya dilakukan kepada siswa yang mewakili kemampuan tinggi, sedang dang rendah. Namun pada tahap ini tidak dilakukan karena keterbatasan dan situasi pandemi saat ini.

Pada proses tahapan field test juga rencananya dilakukan kepada 30 siswa kelas VII SMP dan diperlukannya waktu yang cukup lama karena keterbatasan serta situasi pandemi yang terjadi sehingga tidak dapat mengumpulkan siswa maka tahapan ini tidak dilakukan.

Penelitian pengembangan ini menghasilkan soal untuk kemampuan berpikir kritis matematis siswa yang valid dan praktis. Pengembangan soal ini menggunakan model pengembangan yang mengacu pada Akker (1999) dan Tessmer (1993) sehingga diperoleh soal kemampuan berpikir kritis matematis sebanyak 14 soal pada 
materi aritmatika sosial, soal tersebut sudah valid dan praktis dengan telah melalui tahapan Experts review dan One-to-one.

Penelitian pengembangan ini tidak luput dari kendala dan kekurangan pada saat pelaksanaannya. Beberapa kendala serta kekurangan dalam pelaksanaannya yaitu: 1) Soal kemampuan berpikir kritis matematis yang dikembangkan hanya sebatas pada pokok bahasan aritmatika sosial; 2) Soal kemampuan berpikir kritis matematis dikembangkan hanya sampai pada valid, praktis dan tidak sampai pada karakteristik butir soal yang baik; dan 3) Keterbatasan ujicoba yang hanya dilakukan sampai pada tahapan One-to-one yang disebabkan oleh pandemi covid-19.

\section{SIMPULAN DAN SARAN}

Penelitian ini telah menghasilkan produk soal pada kemampuan berpikir kritis matematis materi aritmatika sosial. Berdasarkan hasil penelitian dan pembahasan dihasilkan kesimpulan bahwa prototype soal yang dihasilkan valid dan praktis. Pengembangan soal kemampuan berpikir kritis yang valid terlihat dari penilaian pada tahap Expert Review dimana semuanya menyatakan soal sudah valid berdasarkan materi, konstruk dan bahasa. Pengembangan soal kemampuan berpikir kritis matematis yang praktis, kepraktisan soal dilihat pada tahap One-to-one bahwa siswa mengerti dan memahami maksud tujuan dari soal dan juga sesuai alur pikiran siswa serta soal mudah dibaca dan jelas.

Berdasarkan hasil penelitian yang telah dilakukan, maka diharapkan soal-soal yang dikembangkan ini dapat digunakan dalam pembelajaran di kelas untuk melatih dan menumbuhkan kemampuan berpikir kritis siswa.

\section{DAFTAR PUSTAKA}

Akker, J. Van de. 1999. Principles and Method of Development Research. London. Dlm. van den Akker, J., Branch, R.M., Gustafson, K., Nieveen, N., \& Plomp, T. (pnyt.)". Design approaches and tools in educational and training. Dordrecht: Kluwer Academic Publisher.

Dirman dan Juarsih, C. 2014. Penilaian dan Evaluasi Dalam Rangka Implementasi Standar Proses Pendidikan Siswa. Jakarta: Rineka Cipta.

Hudojo, H. 2005. Pengembangan Kurikulum dan Pembelajaran Matematika. Malang: UM Press.

Maftukhin, M. 2013. Keefektifan Model Pembelajaran CPS Berbantuan CD Pembelajaran Terhadap Kemampuan Berpikir Kritis Materi Pokok Geometri Kelas X. Skripsi tidak diterbitkan. Semarang: Universitas Negeri Semarang.

Permendiknas No. 22 Tahun 2006 Tentang Standar Isi Untuk Satuan Pendidikan Dasar dan Menengah. Jakarta.

Sugiyono. 2016. Metode Penelitian Kuantitatif, Kualitatif dan R\&D. Bandung: PT. Alfabeta.

Sukardi. 2009. Metodologi Penelitian Pendidikan (Kompetensi dan Praktiknya). Jakarta: Graha Ilmu.

Syahbana, A. 2012. Peningkatan Kemampuan Berpikir Kritis Matematis Siswa SMP Melalui Pendekatan Contextual Teaching and Learning. Edumatica, Vol. 2(1) : 45-57. 
Tessmer, M. 1993. Planning and Conducting Formative Evaluations. London: Routledge.

Turmudi. 2008. Landasan Filsafat dan Teori Pembelajaran Matematika (Berparadigma Eksploratif dan Investigatif). Jakarta : PT. Leuser Cita Pustaka.

Wijaya, C. 2010. Pendidikan Remedial: Sarana Pengembangan Mutu Sumber Daya Manusia. Bandung: Remaja Rosdakarya. 